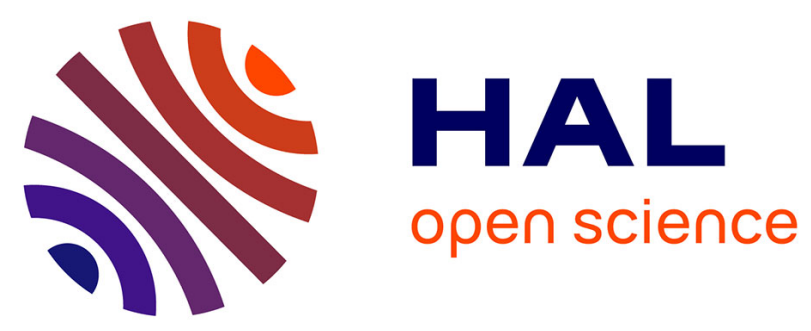

\title{
Study of the inhibition effect of two polymers on calcium carbonate formation by fast controlled precipitation method and quartz crystal microbalance
}

Dimitri Peronno, Hélène Cheap-Charpentier, Olivier Horner, Hubert Perrot

\section{- To cite this version:}

Dimitri Peronno, Hélène Cheap-Charpentier, Olivier Horner, Hubert Perrot. Study of the inhibition effect of two polymers on calcium carbonate formation by fast controlled precipitation method and quartz crystal microbalance. Journal of Water Process Engineering, 2015, 7, pp.11-20. 10.1016/j.jwpe.2015.05.002 . hal-01177848

\section{HAL Id: hal-01177848 \\ https://hal.sorbonne-universite.fr/hal-01177848}

Submitted on 15 Sep 2015

HAL is a multi-disciplinary open access archive for the deposit and dissemination of scientific research documents, whether they are published or not. The documents may come from teaching and research institutions in France or abroad, or from public or private research centers.
L'archive ouverte pluridisciplinaire HAL, est destinée au dépôt et à la diffusion de documents scientifiques de niveau recherche, publiés ou non, émanant des établissements d'enseignement et de recherche français ou étrangers, des laboratoires publics ou privés. 


\title{
Study of the inhibition effect of two polymers on calcium carbonate formation by fast controlled precipitation method and quartz crystal microbalance
}

Dimitri Peronno $^{\mathrm{a}, \mathrm{b}, \mathrm{c}}$, Hélène Cheap-Charpentier ${ }^{\mathrm{a}, \mathrm{b}, \mathrm{c}}$, Olivier Horner ${ }^{\mathrm{a}, \mathrm{b}, \mathrm{c}}$ and Hubert Perrot ${ }^{\mathrm{b}, \mathrm{c}}$ *

${ }^{a}$ EPF Ecole d'Ingénieur, 3 bis rue Lakanal, 92330 Sceaux, France.

${ }^{\mathrm{b}}$ Sorbonne Universités, UPMC Université Paris VI, UMR 8235, Laboratoire Interfaces et Systèmes Electrochimiques (LISE), 4, place Jussieu, case courrier 133, F-75005, Paris, France.

${ }^{\mathrm{c}}$ CNRS, UMR 8235, LISE, F-75005, Paris, France.

* Corresponding author: Tel.: +3314427 7216

E-mail address: hubert.perrot@upmc.fr (H. Perrot)

\begin{abstract}
In this paper, the inhibition efficiency of two inhibitors, namely poly(acrylic acid-co-maleic acid) and polyaspartic acid, towards calcium carbonate scaling was evaluated using fast controlled precipitation (FCP) method and electrochemical quartz crystal microbalance (EQCM). FCP method gave some insight to the calcium carbonate precipitation in solution, whereas EQCM was used to study the calcium carbonate formation on a metallic substrate. It has been shown that these polymers were efficient to delay or to prevent nucleation/growth process, depending on their concentration. Moreover they significantly decreased the crystal growth rate. The FCP method showed that these inhibitors were very efficient at low concentrations ( $\left.4 \mathrm{mg} . \mathrm{L}^{-1}\right)$ when no precipitation occurred. In addition, EQCM showed that the surface coverage of deposits on a substrate was reduced by the presence of these inhibitors at very low concentration $\left(4 \mathrm{mg} . \mathrm{L}^{-1}\right)$. Scanning electronic microscopy and X-Ray diffraction showed that the presence of these polymers modified the morphology of calcium carbonate crystal. In order to model nucleation/growth process of calcium carbonate on surface, masstime transients were interpreted using a 3D model based on a nucleation following a Poisson law associated to vertical and lateral growth rates.
\end{abstract}


Keywords: calcium carbonate; scale inhibitors; fast controlled precipitation method; electrochemical quartz crystal microbalance; nucleation/growth modeling

Abbreviations: EQCM, Electrochemical Quartz Crystal Microbalance; FCP, Fast Controlled Precipitation; PAMA, poly(acrylic acid-co-maleic acid); PASP, polyaspartic acid; SEM, Scanning Electronic Microscopy; XRD, X-Ray Diffraction

\section{Introduction}

Scale deposition (e.g. $\mathrm{CaCO}_{3}, \mathrm{CaSO}_{4}, \mathrm{BaSO}_{4}$ ) is a difficulty encountered in industry and domestic equipment such as heat exchangers [1], in cooling systems [2] and desalination plants [3]. It can cause important technical and economic problems [4, 5] in various industrial processes. Indeed, undesirable scale deposits may cause partial or total obstruction of pipes, limitation of heat exchange or a collapse of the structures. The non-productive expenses related to scaling were estimated at 1.5 milliards euros per year in France [6].

Calcium carbonate $\mathrm{CaCO}_{3}$ is the most abundant component of scales deposited from natural water [7]. It exhibits three polymorphs: vaterite (hexagonal), aragonite (orthorhombic) and calcite (rhombohedric) listed in order of increasing stability [ 8 ]. Calcite is thermodynamically stable at atmospheric pressure within the $0-90^{\circ} \mathrm{C}$ temperature range [9] whereas aragonite and vaterite form metastable phases. It has been shown that vaterite could convert into calcite or aragonite in a later stage of growth [10]. At ambient temperature, $\mathrm{CaCO}_{3}$ precipitates under calcite form.

The precipitation of calcium carbonate occurs in two steps: heterogeneous nucleation step [11] followed by a crystal growth step [12]. It depends on several factors such as ionic activities, $\mathrm{pH}$, temperature, presence of foreign ionic or molecular species $[9,13,14]$, calcium carbonate concentration, water composition, water hardness, presence of additives $[15,16]$ and saturation level of water $[17,18]$.

During the three last decades, several non-electrochemical methods have been developed to study the scaling process in natural waters [19, 20, 21]. Fast controlled precipitation (FCP) method was used to assess the calcium carbonate precipitation in bulk solution. In this technique, precipitation of $\mathrm{CaCO}_{3}$ is accelerated by removing dissolved $\mathrm{CO}_{2}$ under moderate stirring $[22,23]$. It is slow enough to model natural processes. In another study, quartz microbalance allowed studying calcium carbonate deposited thermally [24].

Electrochemical methods (e.g. chronoamperometry [25], electrochemical impedance [26, 27]) have been developed in order to estimate the scaling propensity of waters involving 
calcium carbonate precipitation. Electrochemical precipitation $[28,29,30]$ was usually used as a method to predict scale deposition or to determine inhibitor efficiency. Quartz crystal microbalance coupled with chronoamperometry was used to study $\mathrm{CaCO}_{3}$ deposition $[31,32]$ and the adhesion mechanism of calcareous scaling on a surface [33].

One of the most effective ways to prevent scaling process is to add scale inhibitors in the solution. Indeed, many water soluble additives or polyelectrolytes may influence crystal growth mechanism, nucleation, shape and size of the crystals [34] and polymorph of calcium carbonate [35]. Additives commonly used for scale inhibition are polymers containing carboxylic acid groups such as polyacrylic acid [36, 37, 38], polymaleic acid [38] and polyaspartic acid (PASP) [15,39]. These polymers have important properties including low concentration effect or high temperature endurance. To our knowledge, the copolymer poly(acrylic acid-co-maleic acid) (PAMA) is not widely used as antiscalant $[40,41]$ whereas polyaspartic acid (PASP) is a well-known green inhibitor, in terms of biodegradability, nontoxicity and non-bioaccumulation $[42,43]$.

The aim of our study was to investigate the inhibition effect of poly(acrylic acid-comaleic acid) (PAMA) and polyaspartic acid (PASP) (Figure 1) on the nucleation/growth process of $\mathrm{CaCO}_{3}$ in a bulk and on a metallic surface. The antiscaling performance of PAMA and PASP was studied using FCP and EQCM methods. The kinetics of electrochemical scaling was probed through the measurement and analysis of the mass and current changes with time. Crystal morphology was determined by scanning electronic microscopy (SEM) and $\mathrm{X}$-Ray diffraction (XRD). Moreover, in the present article, nucleation and growth rates were deduced on the basis of an original model discussed in some previous papers $[28,44]$.

\section{Materials and methods}

\subsection{Reactants}

All the experiments were performed in carbonically pure waters, which only contained $\mathrm{Ca}^{2+}$ and $\mathrm{CO}_{3}{ }^{2-}$ ions. The concentration of $\mathrm{Ca}^{2+}$ ions in all test solutions was initially 200 mg. $\mathrm{L}^{-1}$. Preparation of test solutions of calcium carbonate has been previously described [45]. Poly(acrylic acid-co-maleic acid) solution and Poly- $(\alpha, \beta)-\mathrm{D}, \mathrm{L}$ aspartic acid sodium salt powder were purchased from Sigma-Aldrich. The chemical structures of these polymers are shown in Figure 1. Stock solutions of poly(acrylic acid-co-maleic acid) and poly-aspartic acid were prepared in pure water at a concentration of 1 g.L ${ }^{-1}$. 


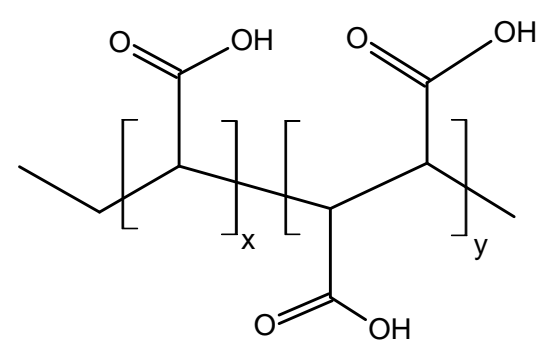

A

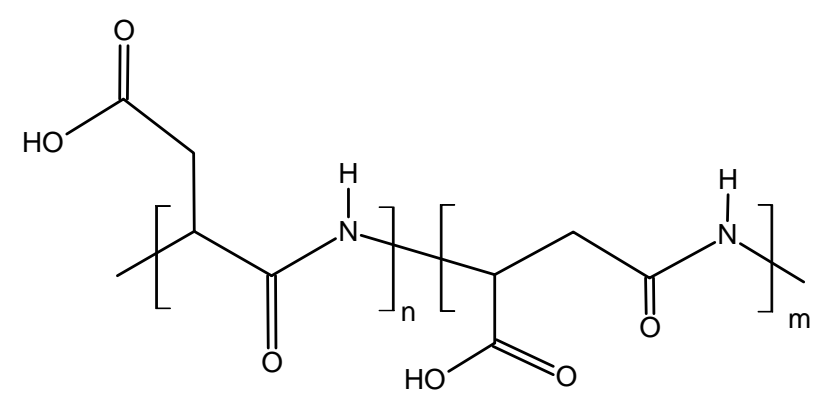

B

Figure 1. Chemical structures of (A) PAMA and (B) PASP.

\subsection{Fast controlled precipitation (FCP) method}

FCP is a technique which allowed the nucleation step and the homogenous precipitation of calcium carbonate in solution in the absence and in the presence of inhibitor to be characterized. The principle of this technique was already detailed elsewhere [45]. All experiments were carried out at $30^{\circ} \mathrm{C}$ and the temperature was controlled by a temperature probe. $\mathrm{pH}$ and resistivity were measured simultaneously using a $\mathrm{pH}$-meter (Radiometer pHM220) and a conductivity-meter (Radiometer CDM230). pH and conductivity electrodes were purchased from Radiometer Analytical. Saturated calomel electrode (SCE, Radiometer Analytical) was used as reference electrode. The full set up was monitored by a PC computer allowing the simultaneous recording of $\mathrm{pH}$ and resistivity as a function of time. The time related to the maximum $\mathrm{pH}$ is characteristic of the time precipitation, $\mathrm{t}_{\mathrm{p}}$. For a given concentration, the scale inhibition efficiency $\mathrm{E}_{\mathrm{FCP}}$ of each inhibitor was calculated as following (Eq. 1):

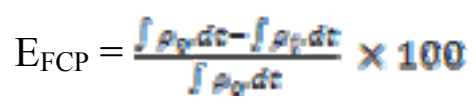

where $\rho_{0}$ and $\rho_{\mathrm{i}}$ are the resistivities of the synthetic water in the absence and in the presence of inhibitor, respectively. The resistivity is more adapted to estimate the inhibitor efficiency as this parameter is a mirror of the evolution of the calcium carbonate concentration.

\subsection{Electrochemical quartz crystal microbalance (EQCM)}

EQCM was performed to measure the mass of calcium carbonate deposited on an active surface and to assess the scaling rate in the absence and in the presence of inhibitor. This 
technique has been previously described elsewhere [31]. The working electrode was a $5 \mathrm{~mm}$ diameter gold disc deposited in a $9 \mathrm{MHz}$ AT cut quartz crystal resonator (Temex); it was adapted in a submerged impinging jet cell. The counter electrode was a large platinum grid. The electrochemical potential applied at the working electrode was maintained at $-1 \mathrm{~V} / \mathrm{SCE}$, which led to the reduction of the dissolved dioxygen according to the electrochemical reaction (Eq. 2):

$$
\mathrm{O}_{2}+2 \mathrm{H}_{2} \mathrm{O}+4 \mathrm{e}^{-} \rightarrow 4 \mathrm{OH}^{-}
$$

The formed hydroxyl ions increased the local $\mathrm{pH}$ near the electrode surface up to 11.2 if no chemical reaction contributed to the consumption of $\mathrm{OH}^{-}$ions $[14,46]$. It leads to $\mathrm{CaCO}_{3}$ precipitation according to Eq. 3:

$$
4 \mathrm{Ca}^{2+}+4 \mathrm{HCO}_{3}^{-}+\mathrm{O}_{2}+4 \mathrm{e}^{-} \rightarrow 4 \mathrm{CaCO}_{3}(\mathrm{~s})+2 \mathrm{H}_{2} \mathrm{O}
$$

The full set up was monitored by a PC computer allowing the simultaneous recording of the current and the frequency change $\Delta \mathrm{f}$ as a function of time. The frequency change $\Delta \mathrm{f}$ of the quartz resonator due to the deposition of the scale on the working electrode was proportional to the mass change $\Delta \mathrm{m}$ according to Sauerbrey equation (Eq. 4) [47]:

$$
\Delta \mathrm{f}=-\mathrm{K}_{\mathrm{s}} \cdot \Delta \mathrm{m}
$$

where $\mathrm{K}_{\mathrm{s}}$ is the sensitivity factor $\left(\mathrm{K}_{\mathrm{s}}\right)^{-1}=1,09 \mathrm{ng}$ per $\mathrm{Hz}$ for an electrode area of $0.2 \mathrm{~cm}^{2}$. The frequency of the oscillator was measured by a frequency-counter (Fluke PM6685).

The current, recorded during calcium carbonate deposition, decreased over time to a residual value. The scaling time needed to reach this residual value was used to compare the effects of different kinds of inhibitors [28]. The scaling rate was determined by the slopes of the current-time and the mass-time curves. The maximum of the curve obtained from the derivative of the mass-time transient as a function of time gave the maximal recovery rate $\left(v_{\bar{R}}^{\max }=\left(\frac{d m}{d t}\right)_{\max }\right)$. The scaling inhibition efficiency $\mathrm{E}_{\mathrm{EQCM}}$ was calculated as following (Eq. 5): 


$$
\mathrm{E}_{\mathrm{EQCM}}=\frac{v_{R}^{\max }-v_{R E}^{\max }}{v_{R \sigma}^{\max }}
$$

where $v_{m 0}^{\max }$ and $v_{E x}^{\max }$ are the maximum of the curve $\mathrm{dm} / \mathrm{dt}=\mathrm{f}(\mathrm{t})$. For a given solution, this curve is obtained from the integration of the mass-time curve as a function of time in the absence and in the presence of inhibitor, respectively.

\subsection{Model of nucleation/growth process of $\mathrm{CaCO}_{3}$}

The evolution of the deposited $\mathrm{CaCO}_{3}$ mass, determined experimentally by EQCM, was modeled using a model of mass - time transients. In a previous study [44], a 2D nucleation and growth model has been used. This model was based on previous models derived from the electrocrystallization process of metal $[48,49]$. In this case, a lateral growth was considered with a constant rate $\mathrm{k}_{1}\left(\mathrm{~mol} \cdot \mathrm{cm}^{-2} \cdot \mathrm{s}^{-1}\right)$. The unit area of substrate was supposed to have a finite number of nucleation active sites $\mathrm{N}_{0}\left(\mu \mathrm{m}^{-2}\right)$. All nucleation events were supposed to be independent of each other. Thus, the probability of nucleation for a given time $t$ depends only on the number of free sites. For non-growing crystals, the density of nuclei (number of nuclei per surface unit), $\mathrm{N}(\mathrm{t})\left(\mu \mathrm{m}^{-2}\right)$, follows a Poisson law (Eq. 6):

$$
\mathrm{N}(\mathrm{t})=\mathrm{N}_{0}[1-\exp (-\mathrm{At})]
$$

where $\mathrm{A}\left(\mathrm{s}^{-1}\right)$ is the nucleation rate constant which gives the rate of conversion of a site into a nucleus.

When At $>>1$, this is instantaneous nucleation. All sites were assumed to be converted into nuclei in the very early stages of the process $\left(\mathrm{N}(\mathrm{t}) \cong \mathrm{N}_{0}\right)$. Conversely, when At $<<1$, this is progressive nucleation. The number of converted sites increased linearly with time $(\mathrm{N}(\mathrm{t}) \cong$ $\left.\mathrm{N}_{0} \mathrm{At}\right)$.

For 3D process used in this paper, vertical growth was considered, i.e. growth in the direction perpendicular to the electrode surface [29]. This vertical growth took place with a constant rate $\mathrm{k}_{\mathrm{v}}\left(\mathrm{mol} \cdot \mathrm{cm}^{-2} \cdot \mathrm{s}^{-1}\right)$. It was assumed that $3 \mathrm{D}$ crystal growth of circular cones occurred on the metallic substrate. The mass $m(t)$ per surface unit, is given by Eq. 7 :

$$
\mathrm{dm}=\rho\left[1-\exp \left(-\mathrm{S}_{\mathrm{ext}}(\mathrm{t}-\mathrm{u})\right)\right] \mathrm{dh}
$$


where $\mathrm{u}$ corresponds to the nucleation time, dh is a thickness of the cone slice at height $\mathrm{h}$ from the electrode area, $\rho$ is the density of the crystal $\left(\rho=2.71 \times 10^{-12}\right.$ g. $\mu \mathrm{m}^{-3}$ for calcite).

The extended surface $S_{\text {ext }}(t)$ is the area which would be covered by all the nuclei at time $t$ without effect of overlap (Eq. 8).

$$
\left.\mathrm{S}_{\mathrm{ext}}(\mathrm{t})=\frac{M K W_{Q}}{2}\left(t-\frac{1}{A}+\frac{1}{A} \exp (-A t)\right)\right)
$$

where $\mathrm{M}$, is the molar mass of $\mathrm{CaCO}_{3}\left(\mathrm{M}=100.1 \mathrm{~g} \cdot \mathrm{mol}^{-1}\right)$.

The total mass per surface unit deposited at the time $t$ on the electrode area is given by Eq. 9:

$$
\mathrm{m}(\mathrm{t})=k_{w 0} M \int_{0}^{t}\left(1-\exp \left(-S_{\mathrm{exz}}(t-u)\right)\right) \times \exp \left(-S_{\operatorname{exc}}(t-u)\right) d u
$$

where $\mathrm{k}_{\mathrm{v} 0}$ is the vertical growth rate constant at $\mathrm{t}=0$.

Moreover, the maximal recovery rate $\left(v_{R}^{\max }\right)$, when the electrode is half recovered by the scale is given by Eq. 10:

$$
\mathrm{V}_{\mathrm{R}}^{\max }=\left(\frac{d m}{d \varepsilon}\right)_{\max }=\frac{k_{\mathrm{we}} \mathrm{X} M}{4}
$$

$\mathrm{v}_{\mathrm{R}}{ }^{\max }$ is independent of electrode surface properties but depends on the $\mathrm{Ca}^{2+}$ concentration, the $\mathrm{pH}$ solution, and the presence of additives.

The calculated curves were calculated using Mathcad software. The density of nuclei was $\mathrm{N}=500[29]$.

\subsection{Characterizations}

After each FCP experiment, the solution was filtered in order to retrieve $\mathrm{CaCO}_{3}$ crystals. Ex situ characterization of calcium carbonate crystals obtained by FCP method was performed by SEM and X-ray diffraction XRD. A SEM imaging with secondary electrons (FEG-SEM Zeiss Ultra55 microscope operated at $10 \mathrm{kV}$ ) was used. XRD was performed using a Diffractometer Panalytical with prefix configuration using the $\mathrm{Cu}-\mathrm{K}_{\alpha}$ radiation $(1.52 \AA)$ at room temperature. Intensities of the diffraction peaks at $2 \theta=29.5^{\circ}\left(\mathrm{I}_{\mathrm{c}}{ }^{104}\right)$ and at $2 \theta=25^{\circ}$ 
$\left(\mathrm{I}_{\mathrm{v}}{ }^{110}\right)$ were used to quantify the calcite and vaterite forms respectively [50]. The molar ratios of calcite $\mathrm{x}_{\mathrm{c}}$ and vaterite $\mathrm{x}_{\mathrm{v}}$ in different samples were given by the following equations (Eq. 11 and 12):

$$
\begin{gathered}
\mathrm{I}_{\mathrm{c}}^{104} / \mathrm{I}_{\mathrm{v}}{ }^{110}=7.691 \times \mathrm{x}_{\mathrm{c}} / \mathrm{x}_{\mathrm{v}} \\
\mathrm{x}_{\mathrm{c}}+\mathrm{x}_{\mathrm{v}}=1
\end{gathered}
$$

\section{Results and discussion}

\subsection{Effect of inhibitors concentrations evaluated by FCP method}

\subsubsection{Addition of PAMA and PASP at the beginning of the FCP experiment}

The scaling inhibition effects of PAMA and PASP were investigated by FCP method. $\mathrm{pH}$ and resistivity evolutions over time, in the absence and in the presence of inhibitors, are shown in Figure 2.
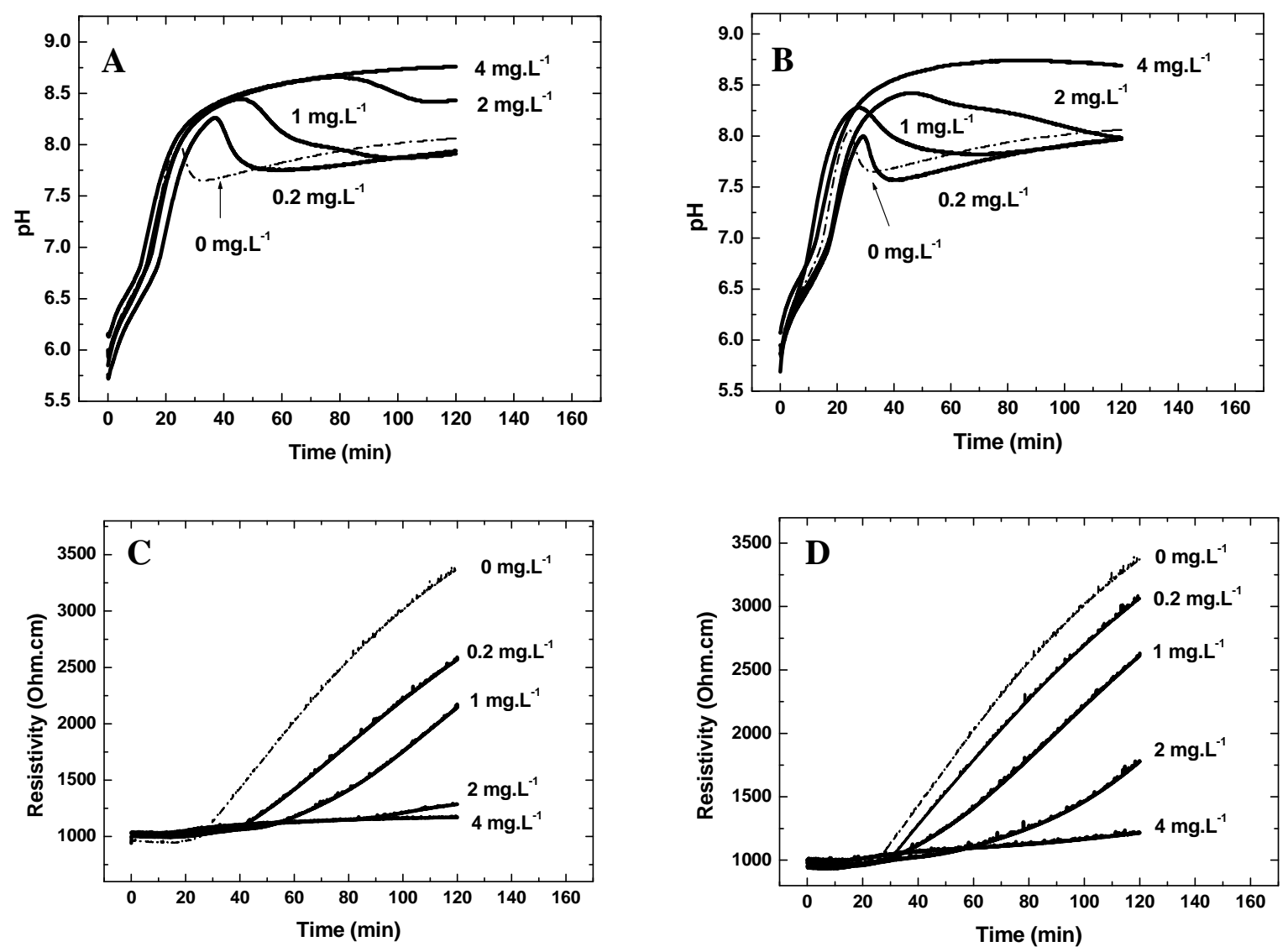
Figure 2. pH-time curves and resistivity-time curves for $(A, C)$ PAMA and (B, D) PASP respectively at concentrations ranging $0-4 \mathrm{mg.L}{ }^{-1}$. Synthetic water containing $\mathrm{Ca}^{2+}$ at $200 \mathrm{mg} . \mathrm{L}^{-1}, 30^{\circ} \mathrm{C}$ and $850 \mathrm{rpm}$.

Typical $\mathrm{pH}$ - time and resistivity - time curves obtained by FCP method for water in the absence of inhibitor have been previously described [45]. The first step of the experiment is characterized by a nucleation step where the $\mathrm{pH}$ increases until a maximal value. This step corresponds to the formation of $\mathrm{CaCO}_{3}$ nuclei in solution [45]. Then, the $\mathrm{pH}$ decreases over time until reaching a constant value. This second step corresponds to the homogeneous precipitation where $\mathrm{CaCO}_{3}$ crystals grow in size and in number in solution [45]. The time of precipitation tp corresponds to the time related to the maximum $\mathrm{pH}$ value (see paragraph 2.2).

Table 1. FCP results for PAMA and PASP

\begin{tabular}{|cccccc|}
\hline & $\begin{array}{c}\mathrm{C} \\
\left(\mathrm{mg.L}^{-1}\right)\end{array}$ & $\mathrm{pH}_{\mathrm{p}}$ & $\mathrm{t}_{\mathrm{p}}(\mathrm{min})$ & $\mathrm{SL}_{\text {limit }}$ & $\mathrm{E}_{\mathrm{FCP}}(\%)$ \\
\hline & 0 & 8.06 & 24 & 50 & - \\
\hline PAMA & 0.2 & 8.26 & 38 & 79 & $51 \%$ \\
\hline & 1 & 8.44 & 48 & 119 & $79 \%$ \\
\hline & 2 & 8.47 & 82 & 198 & $98 \%$ \\
\hline PASP & 4 & - & - & - & $100 \%$ \\
\hline & 0.2 & 8.00 & 29 & 43 & $21 \%$ \\
\hline & 1 & 8.28 & 28 & 82 & $48 \%$ \\
\hline 2 & 8.42 & 49 & 114 & $84 \%$ \\
\hline 4 & - & - & - & $100 \%$ \\
\hline
\end{tabular}

$\mathrm{C}$ : concentration; $\mathrm{pH}_{\mathrm{p}}$ : precipitation $\mathrm{pH}, \mathrm{t}_{\mathrm{p}}$ : precipitation time; $\mathrm{SL}_{\text {limit }}$ : limit saturation level; $\mathrm{E}_{\mathrm{FCP}}$ : inhibition efficiency calculated from FCP method

In this work, precipitation time $\mathrm{t}_{\mathrm{p}}$ of $\mathrm{CaCO}_{3}$ in water without inhibitor is $24 \mathrm{~min}$ (Table 1). This value of $t_{p}$ is used to compare the scaling inhibition capacity of inhibitors. The nucleation and growth processes can be also determined by an analysis of the resistivity vs time curve. Indeed, when the homogeneous precipitation occurs, the solution resistivity drastically increases over time. The slope of the resistivity - time curves is generally used to assess growth rates [51]. The comparison of the slopes allows determining the effects of the inhibitors on the calcium carbonate crystal growth rate.

Figures $2 \mathrm{~A}$ and $2 \mathrm{~B}$ show the evolution of $\mathrm{pH}$ over time depending on the concentrations of PAMA and PASP respectively. In the presence of PAMA and PASP, precipitation time $t_{p}$ 
increases with inhibitor concentration (Table 1). For example, for $2 \mathrm{mg} . \mathrm{L}^{-1}$ PAMA, $\mathrm{t}_{\mathrm{p}}$ is 82 min whereas it is only 48 for PAMA $1 \mathrm{mg} . \mathrm{L}^{-1}$. The nucleation step is much longer and the homogeneous $\mathrm{CaCO}_{3}$ precipitation is delayed when inhibitor is added. This suggests that PAMA and PASP may act as nucleation inhibitors.

Figures 2C and 2D show the evolution of resistivity over time depending on the concentrations of PAMA and PASP, respectively. In the presence of PAMA and PASP, the homogeneous precipitation rate decreases when inhibitor concentration increases. Nevertheless, for inhibitor concentrations ranging 0.2 to $1 \mathrm{mg} . \mathrm{L}^{-1}$, precipitation rate slightly decreases. At these concentrations, the presence of PAMA and PASP may have a small effect on the crystal growth rate. From $2 \mathrm{mg} . \mathrm{L}^{-1}$ inhibitor, precipitation rate drastically decreases. Above this concentration, PAMA and PASP have a significant inhibition effect on crystal growth rate.

Finally, no precipitation of $\mathrm{CaCO}_{3}$ occurred for $4 \mathrm{mg} . \mathrm{L}^{-1}$ PAMA and PASP (no pH decrease and constant resistivity values observed over time) (Figures $2 \mathrm{~A}$ and $2 \mathrm{~B}$ ). For this concentration, PAMA and PASP totally inhibit $\mathrm{CaCO}_{3}$ precipitation (Table 1).

It must be noticed that at the same concentration $\left(2 \mathrm{mg} \cdot \mathrm{L}^{-1}\right)$, PAMA is more efficient than PASP (Figure 3). PAMA delayed more $\mathrm{CaCO}_{3}$ precipitation $\left(t_{p}=82 \mathrm{~min}\right)$ than PASP $\left(t_{p}\right.$ $=49 \mathrm{~min}$ ) and the nucleation time is much longer for the same concentration. Moreover, in the presence of PAMA, precipitation rate decreases more drastically than in the presence of PASP, as shown by the slope of resistivity curve (Figure 3B). Indeed the inhibition efficiency is $98 \%$ and $84 \%$ for PAMA and PASP respectively (Table 1 ).
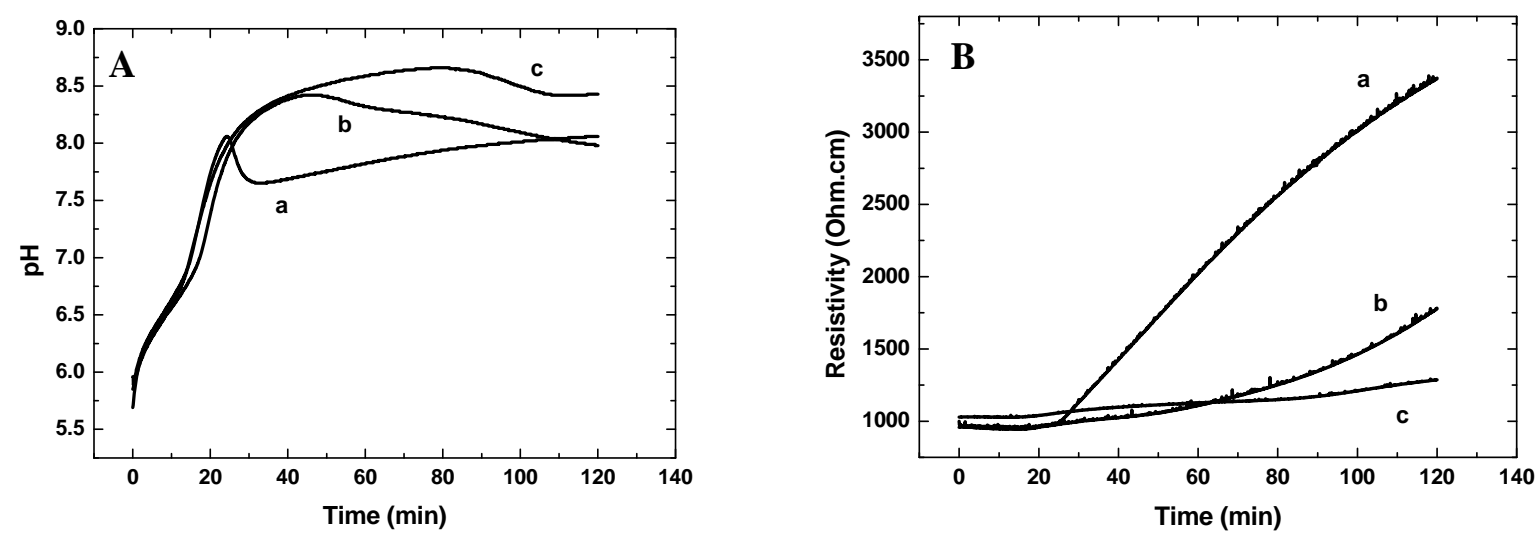

Figure 3. Comparison of (A) $\mathrm{pH}$ and (B) resistivity evolutions plotted against time for: (a) no inhibitor, (b) PASP 2 mg.L ${ }^{-1}$ and (c) PAMA 2 mg.L ${ }^{-1}$. Synthetic water containing $\mathrm{Ca}^{2+}$ at $200 \mathrm{mg} . \mathrm{L}^{-1}, 30^{\circ} \mathrm{C}, 850 \mathrm{rpm}$. 


\subsubsection{Addition of PAMA after the homogeneous precipitation}

In order to determine if the inhibitor affects the crystal growth process, $2 \mathrm{mg} . \mathrm{L}^{-1}$ of PAMA were added a few minutes after the beginning of the massive precipitation (Figure 4).

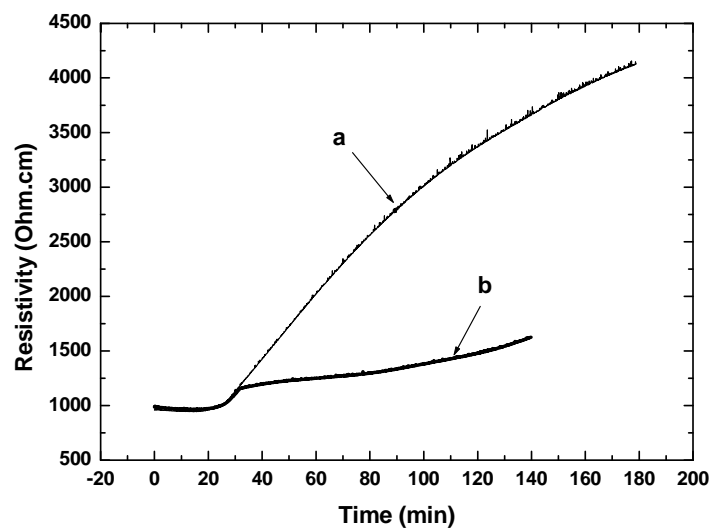

Figure 4. Resistivity change plotted against time. Solution of $\mathrm{CaCO}_{3}$ with (a) no inhibitor and (b) PAMA 2 mg. $\mathrm{L}^{-1}$ added 4 minutes after the beginning of the massive precipitation. Synthetic water containing $\mathrm{Ca}^{2+}$ at $200 \mathrm{mg} . \mathrm{L}^{-1}, 30^{\circ} \mathrm{C}, 850 \mathrm{rpm}$.

The slope of the resistivity curve thoroughly decreases compared to a solution without inhibitor (Figure 4A). PAMA might prevent the growth of $\mathrm{CaCO}_{3}$ crystal, acting as a growth inhibitor, or strongly slow down the precipitation rate of calcium carbonate. Therefore PAMA could act as a growth inhibitor. Euvrard et al. [52] have studied the inhibition effect of PASP and polymaleic acid on the growth of calcium carbonate by adding these polymers few minutes after crystallization. They observed that the added polymers blocked crystal growth. However, polymaleic acid totally blocked crystal growth whereas PASP only partially blocked. Our results are consistent to those obtained by these authors. Indeed, all these polymers have similar structure with carboxylate groups. This may explain the same behavior towards inhibition of calcium carbonate precipitation.

\subsection{SEM and XRD analysis}

After each FCP experiment, the solution was filtered in order to retrieve $\mathrm{CaCO}_{3}$ crystals. The morphologies of these crystals were observed using SEM (Figures 5A to 5D). In the absence of PAMA or PASP, crystal surface is rough and crystals have a cauliflower-shaped 
morphology which is characteristic of vaterite (Figure 5A). This assessment was confirmed by the spectrum obtained by X-ray diffraction (XRD), which revealed mainly characteristic peaks of vaterite (Figure 5E).
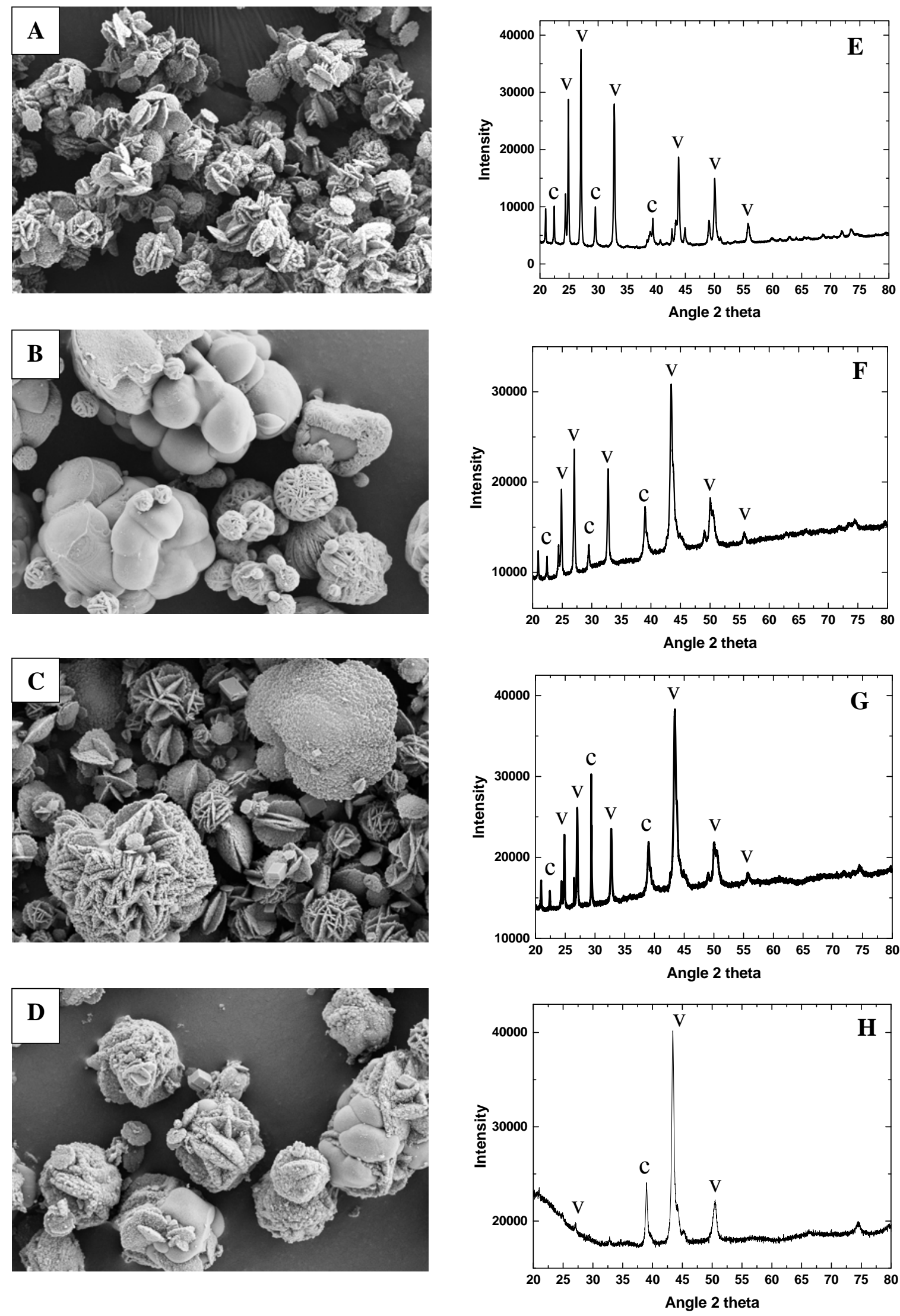
Figure 5. SEM images and XRD spectra respectively for $\mathrm{CaCO}_{3}$ crystals (A and $\mathrm{E}$ ) in the absence of inhibitor, and in the presence of (B and F) PAMA 2 mg. $\mathrm{L}^{-1}$, (C and G) PASP 2 mg. $\mathrm{L}^{-1}$ and (D and H) PASP 4 mg.L ${ }^{-1}$. (c: calcite; v: vaterite)

SEM images of calcium carbonate crystals reveal changes in the shape of $\mathrm{CaCO}_{3}$ crystals due to the presence of PAMA or PASP. In the presence of PASP $2 \mathrm{mg} . \mathrm{L}^{-1}$ (Figure 5C), a slightly difference was observed on the shape of crystals compared to those formed without inhibitor. Indeed, the crystals with flat shape have been formed. Greater changes in the morphology have been observed with PAMA 2 mg.L ${ }^{-1}$, and PASP 4 mg.L L $^{-1}$ (Figures $5 \mathrm{~B}$ and 5D). Crystals present a smooth surface compared to the crystals formed without inhibitor. Thus PAMA and PASP contributed to the distortion of $\mathrm{CaCO}_{3}$ crystals. These images highlight the fact that PAMA $2 \mathrm{mg} . \mathrm{L}^{-1}$ is more efficient than PASP $4 \mathrm{mg} . \mathrm{L}^{-1}$.

The presence of $\mathrm{CaCO}_{3}$ polymorphs was determined par XRD in the absence and in the presence of PAMA or PASP (Figures 5E to $5 \mathrm{H}$ ). The peak analysis revealed that aragonite was never present; only vaterite $(94 \pm 1 \%)$ and calcite $(6 \pm 1 \%)$ were formed in our experimental conditions (in the absence or presence of inhibitors). In a typical aqueous system, calcium carbonate first nucleates and precipitates in the vaterite form and then, transform into a more stable phase (aragonite or calcite) over time [53]. By FCP method, the precipitation of $\mathrm{CaCO}_{3}$ is very fast leading to vaterite formation. Moreover, PAMA and PASP may adsorb onto active sites of crystal thus stabilizing vaterite form and delaying the formation of calcite form. Sinn et al. [54] compared the inhibitor effect of three polymers: polyacrylate, polyaspartic acid (PASP) and poly(acrylic acid-co-maleic acid) (PAMA). They concluded that the polymer's ability to suppress calcite formation was due to the binding between carboxylate groups and calcium ions. In a recent work, Martinod et al. [55] studied the inhibition effect of polyaspartic acid. They demonstrated that PASP led to vaterite formation while calcite was obtained in solutions without inhibitor.

\subsection{Effect of inhibitor concentrations evaluated by EQCM}

The scaling inhibition effect of the inhibitors on the formation of $\mathrm{CaCO}_{3}$ onto an electrode surface has been investigated using EQCM.

In a typical mass - time curve obtained by the EQCM method in the absence of inhibitor, the mass increases over time when calcium carbonate is progressively formed on the electrode surface. The time corresponding to the beginning of the nucleation step $\left(t_{N}\right)$ is determined when the curve begins increasing. The time necessary to totally recover the electrode surface 
$\left(t_{R}\right)$ is determined when the mass reaches a plateau. The gold electrode surface was progressively recovered by an isolating layer of $\mathrm{CaCO}_{3}$ so the access to the active surface was blocked which was highlighted by a decrease of the current over time [56].

A

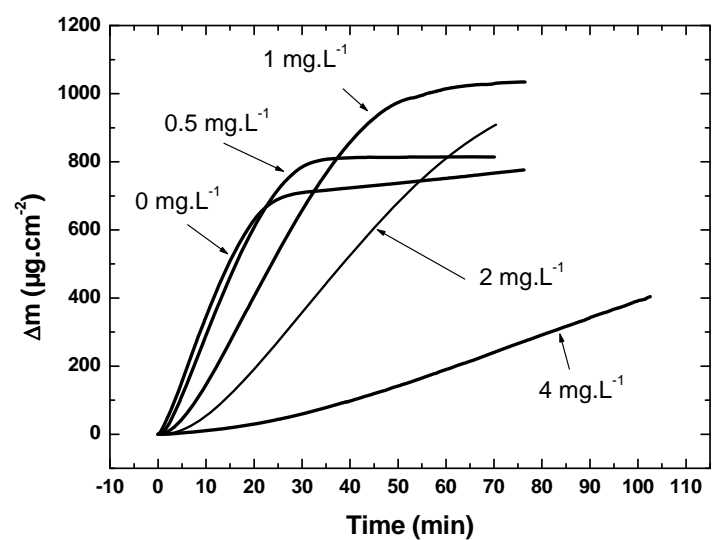

$\mathrm{C}$

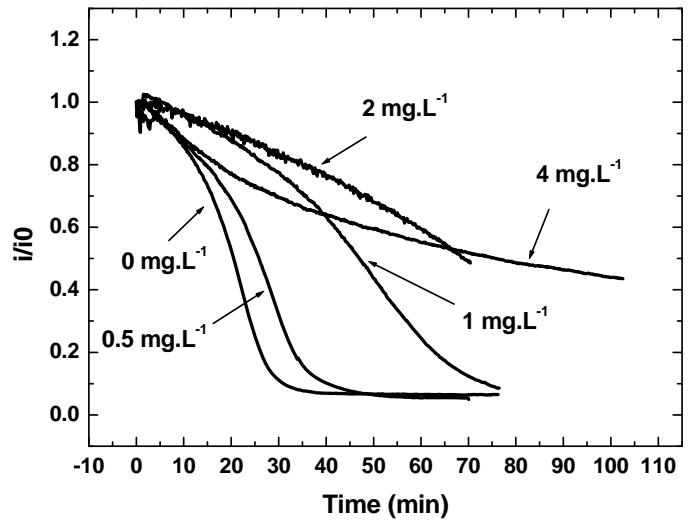

B

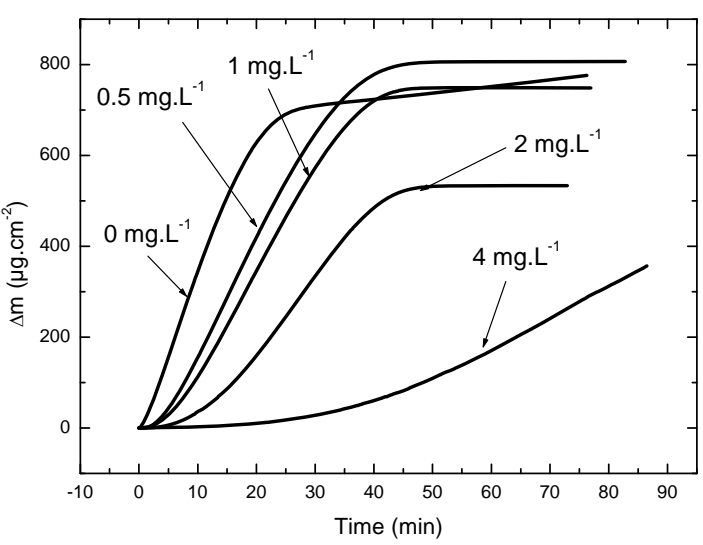

$\mathrm{D}$

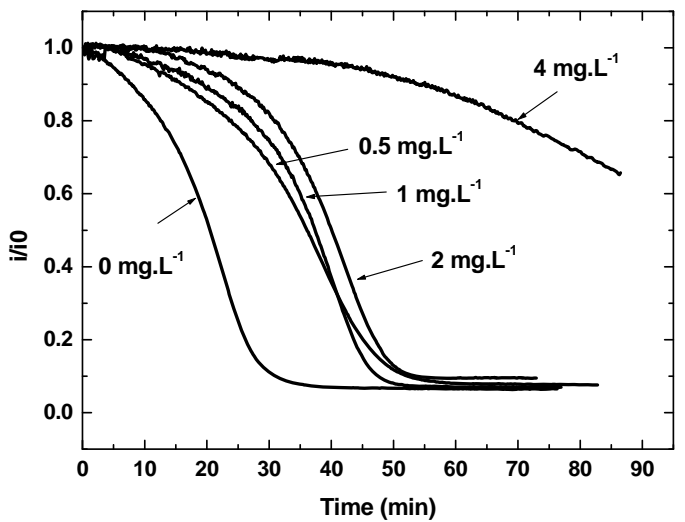

Figure 6. Evolutions of mass and relative current changes during $\mathrm{CaCO}_{3}$ deposition in the presence of (A, C) PAMA and (B, D) PASP respectively at concentration ranging 0 4 mg. $\mathrm{L}^{-1}$. Synthetic water containing $\mathrm{Ca}^{2+}$ at 200 mg.L ${ }^{-1}, 30^{\circ} \mathrm{C}$.

Table 2. EQCM results for PAMA and PASP

\begin{tabular}{|cccccc|}
\hline & $\begin{array}{c}\mathrm{C} \\
\left(\mathrm{mg} . \mathrm{L}^{-1}\right)\end{array}$ & $\mathrm{t}_{\mathrm{N}}(\min )$ & $\mathrm{t}_{\mathrm{R}}(\min )$ & $\mathrm{V}_{\mathrm{R}}{ }^{\max }$ & $\mathrm{E}_{\mathrm{EQCM}}(\%)$ \\
\hline PAMA & 0 & 1 & 20 & 40 & \\
\hline & 0.5 & 2 & 25 & 37 & $7.8 \%$ \\
\hline & 1 & 4.5 & 45 & 26 & $33.5 \%$ \\
\hline PASP & 2 & 7 & 62 & 17 & $57.2 \%$ \\
\hline & 0.5 & 4 & 36 & 27 & $31.4 \%$ \\
\hline & 1 & 6 & 37 & 24 & $39.0 \%$ \\
\hline
\end{tabular}

$t_{N}$ : nucleation time; $t_{R}:$ recovery time 
Figures $6 \mathrm{~A}$ and $6 \mathrm{~B}$ show the mass evolution over time in the presence of PAMA and PASP respectively. We can notice that the curves for 0.5 and $1 \mathrm{mg} . \mathrm{L}^{-1}$ are below the curve related to the raw water. The final mass is related to the precipitation process and can differ drastically in the absence or presence of these molecules. It is not a basic shift of the kinetics of the calcareous film formation. In the absence of inhibitor, $t_{N}$ is 1 min (Table 2). In the presence of PAMA or PASP, $t_{N}$ increases with inhibitor concentration. For example, in the presence of PASP $1 \mathrm{mg} . \mathrm{L}^{-1}, \mathrm{t}_{\mathrm{N}}$ is 6 min whereas $\mathrm{t}_{\mathrm{N}}$ is $9.5 \mathrm{~min}$ for PASP $2 \mathrm{mg} . \mathrm{L}^{-1}$ (Table 2). The time necessary to totally recover the gold surface $\left(t_{R}\right)$ is $20 \mathrm{~min}$ without inhibitor. The recovery time $t_{R}$ also increases with inhibitor concentration. For instance, in the presence of PAMA 1 and $2 \mathrm{mg} . \mathrm{L}^{-1}, \mathrm{t}_{\mathrm{R}}$ are 44 and $62 \mathrm{~min}$ respectively (Table 2). Moreover, the recovery rate $v_{R}{ }^{m a x}$ decreases when the concentration of PAMA or PASP increases (Table 2). The same result could be obtained by the comparison of the slope of the mass - time curve (Figure 6A and 6B). Thus, PAMA and PASP may act as nucleation inhibitor and growth as seen by FCP method (see paragraph 3.1.1). The presence of these inhibitors slowed down the calcium carbonate precipitation on the electrode surface. The inhibition efficiency, calculated from $\mathrm{v}_{\mathrm{R}}{ }^{\mathrm{max}}$, increased with PAMA or PASP concentration. For example, in the presence of PAMA 1 and $2 \mathrm{mg} . \mathrm{L}^{-1}$, $\mathrm{E}_{\mathrm{EQCM}}$ were $33.5 \%$ and $57.2 \%$ respectively (Table 2).

Figures $6 \mathrm{C}$ and $6 \mathrm{D}$ show the current changes over time in the presence of PAMA and PASP respectively. The presence of PAMA or PASP in synthetic water reduced the surface coverage of deposits on the gold substrate. In the presence of PAMA 2 and $4 \mathrm{mg} . \mathrm{L}^{-1}$, the gold surface was not totally recovered (Figure 6C) even at long times as $60 \mathrm{~min}$. Indeed the current remained at high values. However, PAMA is more efficient than PASP. Indeed, in the presence of PASP $2 \mathrm{mg} . \mathrm{L}^{-1}$, the gold surface was totally recovered whereas in the presence of PAMA at the same concentration, the surface was not (Figure 6D). This is in line with the result obtained by FCP method (see paragraph 3.1.1).

Recently, Euvrard et al. [52] studied the inhibition effect of PASP and polymaleic acid on the growth of calcium carbonate on a metallic substrate. They suggested that polymers containing carboxylic groups adsorb onto cationic sites of crystals. Wada et al. [57] suggested that the degree of growth inhibition depended on the number of carboxyl groups present in the molecule. Indeed, PAMA has three carboxyl groups in its monomer structure whereas PASP has only two. The blocking of active sites should be more efficient for PAMA than for PASP, as demonstrated by FCP and EQCM methods. This may explain that PAMA is more efficient than PASP at the same concentration by FCP method and EQCM. Polyacrylate molecules 
were successfully used to slow the growth of calcium carbonate. Tribello et al. [58] showed that calcium complexed with both carbonate and polyacrylate and these complexes formed very stable species. The authors suggested that these complexes forced these molecules into an arrangement thus the crystal growth was hindered. They also supposed that polyacrylate strongly binds calcium - carbonate pairs from solution, thereby preventing their further diffusion and the crystal growth.

In this study, the $\mathrm{CaCO}_{3}$ precipitation in a bulk solution has been studied using FCP method whereas the $\mathrm{CaCO}_{3}$ formation on a metallic substrate has been evaluated by EQCM method. Both methods strongly suggest that PAMA and PASP act as nucleation and growth inhibitors and that PAMA is more efficient than PASP.

By FCP, the inhibition was totally efficient for PAMA and PASP $4 \mathrm{mg} . \mathrm{L}^{-1}$. Nevertheless, at the same concentration, the formation of $\mathrm{CaCO}_{3}$ onto a metallic surface was only delayed since a slight deposit was observed on the electrode surface by the EQCM method.

No difference of $\mathrm{v}_{\mathrm{R}}{ }^{\max }$ values, calculated from EQCM method, was observed between PAMA and PASP (Table 2) whereas a great difference of growth rate has been determined by FCP method (Figures 2C and 2D). FCP method would be more efficient to assess the inhibition effect of PAMA or PASP on the crystal growth rate in solution.

\subsection{Model of $\mathrm{CaCO}_{3}$ growth}

It has been shown by XRD that calcite was formed on the gold surface during the electrodeposition. Figure 7 shows experimental and calculated mass - time transients plotted with respect to time in the absence and in the presence of inhibitor (PAMA and PASP). Satisfactory fittings were observed between experimental and calculated curves. The 3D model proposed by Gabrielli et al. [29] seemed appropriated to modelling the nucleation / growth of calcium carbonate in the absence or presence of inhibitor. Table 3 shows the results obtained from the fitting process. 

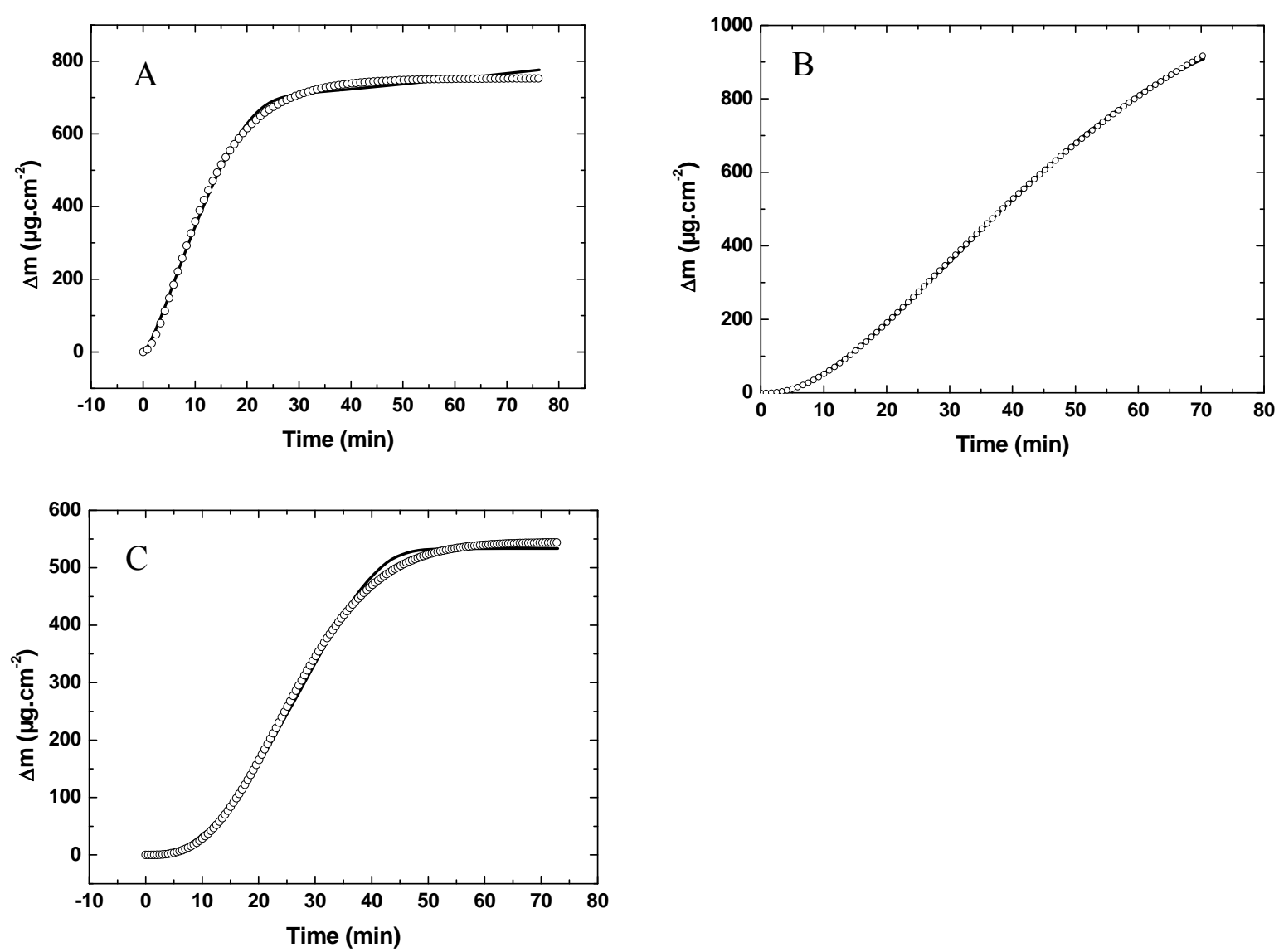

Figure 7. Evolution of the deposited mass in function of time, (-) experimental mass, (o) calculated mass. (A) No inhibitor, (B) PAMA 2 mg. $\mathrm{L}^{-1}$ and (C) PASP 2 mg. $\mathrm{L}^{-1}$. Synthetic water containing $\mathrm{Ca}^{2+}$ at $200 \mathrm{mg} \cdot \mathrm{L}^{-1}, 30^{\circ} \mathrm{C}$.

Table 3. Results of the model of nucleation / growth process

\begin{tabular}{|cccccc|}
\hline & $\begin{array}{c}\mathrm{C} \\
\left(\mathrm{mg} . \mathrm{L}^{-1}\right)\end{array}$ & $\begin{array}{c}\mathrm{k}_{1} \\
\left(\mathrm{~mol} . \mathrm{cm}^{-1} \cdot \mathrm{s}^{-1}\right)\end{array}$ & $\begin{array}{c}\mathrm{k}_{\mathrm{v} 0} \\
\left(\mathrm{~mol} . \mathrm{cm}^{-1} \cdot \mathrm{s}^{-1}\right)\end{array}$ & $\mathrm{A}\left(\mathrm{s}^{-1}\right)$ & $\mathrm{R}^{2}$ \\
\hline PAMA & 0 & $6.3 \times 10^{-6}$ & $1.8 \times 10^{-6}$ & $1.7 \times 10^{+7}$ & 0.99 \\
\hline & 0.5 & $6.1 \times 10^{-6}$ & $1.8 \times 10^{-6}$ & 0.39 & 0.97 \\
\hline PASP & 1 & $3.2 \times 10^{-6}$ & $1.2 \times 10^{-6}$ & 0.21 & 0.98 \\
\hline & 2 & $1.4 \times 10^{-6}$ & $6.7 \times 10^{-7}$ & 0.56 & 0.99 \\
\hline & 0.5 & $5.6 \times 10^{-6}$ & $1.3 \times 10^{-6}$ & 0.094 & 0.97 \\
\hline & 1 & $7.1 \times 10^{-6}$ & $1.2 \times 10^{-6}$ & 0.046 & 0.96 \\
\hline
\end{tabular}

In the absence of inhibitor, lateral growth rate $\mathrm{k}_{1}$ is $6.31 .8 \times 10^{-6} \mathrm{~mol} . \mathrm{cm}^{-2} \cdot \mathrm{s}^{-1}$ (Table 3).

Martinod et al. used this model to calculate $\mathrm{k}_{1}$ in synthetic water whose composition is close to North Sea [59]. In their conditions and in the absence of inhibitor, $\mathrm{k}_{1}$ was $1.4 \times 10^{-11}$ 
mol. $\mathrm{cm}^{-2} \cdot \mathrm{s}^{-1}$. This value is lower than that one we have determined. It may be due to a difference in the composition of synthetic water and the electrode surface.

In the presence of PAMA, the lateral growth rate $\mathrm{k}_{1}$ decreases when PAMA concentration increases (Table 3). PAMA seems to have an inhibition effect on the lateral formation of crystal. For PAMA $1 \mathrm{mg} \cdot \mathrm{L}^{-1}, \mathrm{k}_{1}$ was $3.2 \times 10^{-6} \mathrm{~mol} . \mathrm{cm}^{-2} \cdot \mathrm{s}^{-1}$ (Table 3). Martinod et al. also used this model to calculate $\mathrm{k}_{1}$ in the presence of polymaleic acid (PMA). They found that $\mathrm{k}_{1}$ was $1.4 \times 10^{-11} \mathrm{~mol} . \mathrm{cm}^{-2} \cdot \mathrm{s}^{-1}$ in the presence of PMA $1 \mathrm{mg} \cdot \mathrm{L}^{-1}$ [59]. In their study, at this concentration, PMA did not act on the growth stage because their value of $\mathrm{k}_{1}$ is similar to this of the reference water.

On the contrary, the presence of PASP would accelerate this process since $\mathrm{k}_{1}$ increases with PASP concentration. For PASP $2 \mathrm{mg} \cdot \mathrm{L}^{-1}, \mathrm{k}_{1}$ is $1.9 \times 10^{-3} \mathrm{~mol} \cdot \mathrm{cm}^{-2} \cdot \mathrm{s}^{-1}$. This value is very high which may explain the flat form of crystal observed by SEM (Figure 5C).

The vertical growth rate $\mathrm{k}_{\mathrm{v} 0}$ at time $\mathrm{t}=0$, decreases when PAMA or PASP concentration increases (Table 3). In the absence of inhibitor, $\mathrm{k}_{\mathrm{v} 0}$ is $1.8 \times 10^{-6} \mathrm{~mol}_{\mathrm{cm}} \mathrm{cm}^{-2} \mathrm{~s}^{-1}$. In the presence of PAMA $2 \mathrm{mg} . \mathrm{L}^{-1}$ and PASP $2 \mathrm{mg} . \mathrm{L}^{-1}, \mathrm{k}_{\mathrm{v} 0}$ are $6.9 \times 10^{-7}$ and $7.5 \times 10^{-7} \mathrm{~mol} . \mathrm{cm}^{-2} . \mathrm{s}^{-1}$ respectively. This could explain the change of morphology of calcium carbonate crystals observed by SEM in the presence of PAMA or PASP compared to those obtained without inhibitor (Figures 5A to 5D).

The nucleation rate constant $\mathrm{A}$ is $1.7 \times 10^{+7} \mathrm{~s}^{-1}$ in the absence of inhibitor. This value is very high which means that nucleation is instantaneous and that all sites are converted into nuclei in the very early stages of the process (see paragraph 2.4). In the presence of PAMA, A value drastically decreases with a factor $10^{8}$ and remained at constant value when PAMA concentration increases (Table 3 ). In this case, the nucleation was progressive. In the presence of PASP 0.5 and $1 \mathrm{mg} . \mathrm{L}^{-1}$, A value decreases more drastically with a factor $10^{9}$ compared to the value obtained without inhibitor. For PASP $2 \mathrm{mg} . \mathrm{L}^{-1}$, A value decreases in more important way and is equal to $7.5 \times 10^{-5} \mathrm{~s}^{-1}$. At this concentration, PASP seems to prevent nucleation process. Thus, PAMA and PASP might have an inhibition effect on the nucleation process as suggested by FCP and EQCM methods (see paragraph 3.1.1 and 3.3).

\section{Conclusion}

In this work, scale inhibition abilities of two polymers, namely polyaspartic acid (PASP) and poly(acrylic acid-Co-maleic acid) (PAMA), on the formation of calcium carbonate were investigated using FCP method and EQCM. These methods could be used to assess the 
efficiency of these inhibitors. In the first set of experiments, the inhibition effects of the polymers on the nucleation / growth of $\mathrm{CaCO}_{3}$ formed in solution were studied using FCP method. PASP and PAMA were efficient to delay or to prevent scaling process depending on their concentration. Both inhibitors were very efficient at very low concentration because no

precipitation was observed at $4 \mathrm{mg} \cdot \mathrm{L}^{-1}$. The inhibition effect of the two polymers on the formation of $\mathrm{CaCO}_{3}$ onto a metallic surface was investigated using EQCM. The presence of PAMA or PASP reduced the surface coverage of deposits on the electrode and the scaling rate.

PASP and PAMA led to modifications in the morphology of $\mathrm{CaCO}_{3}$ particles as observed by SEM. These inhibitors distorted the crystal lattice of the precipitates, thus delayed the formation of $\mathrm{CaCO}_{3}$ crystal. When PAMA was added few minutes after the beginning of $\mathrm{CaCO}_{3}$ precipitation, it highly decreased the growth of crystals. As a consequence, these polymers affected the growth of $\mathrm{CaCO}_{3}$. The proportion of each crystalline phase was evaluated by XRD analysis. Vaterite polymorph was formed in greater quantity than calcite.

PAMA seemed to be more efficient than PASP because it has more carboxyl groups in its structure than PASP.

The 3D model developed by Gabrielli et al. seemed to be appropriated to model the nucleation / growth process of calcium carbonate crystals in the absence or presence of inhibitors. Different parameters such as the lateral growth rate $\mathrm{k}_{1}$, the vertical growth rate $\mathrm{k}_{\mathrm{v} 0}$ and the nucleation rate A could be calculated thanks to this mode. It has been shown that PAMA and PASP affect the nucleation process. Surprisingly, PASP would accelerate the lateral growth whereas PAMA would slow down this process. Both PAMA and PASP have an inhibition effect on the nucleation rate and the vertical growth rate.

\section{Acknowledgments}

The authors thank Françoise Pillier and Cyrille Bazin (LISE) for technical assistance on SEM acquisitions and X-Ray diffraction experiment, respectively. 


\section{Figure captions}

Figure 1. Chemical structures of (A) PAMA and (B) PASP.

Figure 2. pH-time curves and resistivity-time curves for (A, C) PAMA and (B, D) PASP respectively at concentrations ranging $0-4 \mathrm{mg} . \mathrm{L}^{-1}$. Synthetic water containing $\mathrm{Ca}^{2+}$ at 200 mg. $\mathrm{L}^{-1}, 30^{\circ} \mathrm{C}$ and $850 \mathrm{rpm}$.

Figure 3. Comparison of (A) $\mathrm{pH}$ and (B) resistivity evolutions plotted against time for: (a) no inhibitor, (b) PASP $2 \mathrm{mg} . \mathrm{L}^{-1}$ and (c) PAMA $2 \mathrm{mg} . \mathrm{L}^{-1}$. Synthetic water containing $\mathrm{Ca}^{2+}$ at $200 \mathrm{mg} . \mathrm{L}^{-1}, 30^{\circ} \mathrm{C}, 850 \mathrm{rpm}$.

Figure 4. Resistivity change plotted against time. Solution of $\mathrm{CaCO}_{3}$ with (a) no inhibitor and (b) PAMA $2 \mathrm{mg} \cdot \mathrm{L}^{-1}$ added 4 minutes after the beginning of the massive precipitation. Synthetic water containing $\mathrm{Ca}^{2+}$ at $200 \mathrm{mg} . \mathrm{L}^{-1}, 30^{\circ} \mathrm{C}, 850 \mathrm{rpm}$.

Figure 5. SEM images and XRD spectra respectively for $\mathrm{CaCO}_{3}$ crystals (A and E) in the absence of inhibitor, and in the presence of (B and F) PAMA $2 \mathrm{mg} . \mathrm{L}^{-1}$, (C and G) PASP 2 mg. $\mathrm{L}^{-1}$ and (D and H) PASP 4 mg. $\mathrm{L}^{-1}$. (c: calcite; v: vaterite)

Figure 6. Evolutions of mass and relative current changes during $\mathrm{CaCO}_{3}$ deposition in the presence of $(\mathrm{A}, \mathrm{C})$ PAMA and $(\mathrm{B}, \mathrm{D})$ PASP respectively at concentration ranging $0-4 \mathrm{mg} . \mathrm{L}^{-}$ ${ }^{1}$. Synthetic water containing $\mathrm{Ca}^{2+}$ at $200 \mathrm{mg} \cdot \mathrm{L}^{-1}, 30^{\circ} \mathrm{C}$.

Figure 7. Evolution of the deposited mass in function of time, (-) experimental mass, (o) calculated mass. (A) No inhibitor, (B) PAMA $2 \mathrm{mg} \cdot \mathrm{L}^{-1}$ and (C) PASP 2 mg. $\mathrm{L}^{-1}$. Synthetic water containing $\mathrm{Ca}^{2+}$ at $200 \mathrm{mg} \cdot \mathrm{L}^{-1}, 30^{\circ} \mathrm{C}$.

\section{Table captions}

Table 1. FCP results for PAMA and PASP

Table 2. EQCM results for PAMA and PASP

Table 3. Results of the model of nucleation / growth process 


\section{References}

[1] Q. Yang, Investigation of induction period and morphology of $\mathrm{CaCO}_{3}$ fouling on heated surface, Chemical Engineering Science 57 (2002) 921 - 931.

[2] W. Girasa, M. De Wispelaere, Polyaspartate, a New Alternative for the Conditioning of Cooling Water, 14th International Conference on the Properties of Water and Steam, Kyoto, Japan, 29 Août, 3 Septembre 2004.

[3] A.P. Morizot, A. Neville, Insights into electrodeposition of an inhibitor film and its inhibitive effects on calcium carbonate deposition, Journal of Colloid and Interface Science 245 (2002) $40-49$.

[4] L. Legrand, P. Leroy, Prevention of corrosion and scaling in water supply systems, Ellis Horwood Series in Water and waste Technology, New York (1990).

[5] H. Roques, Fondements théoriques du traitement chimiques des eaux, Tec. Et Doc, Lavoisier, Paris (1990).

[6] R. Rosset, Les procédés physiques antitartres : mythe ou réalité, Actualité Chimique (1992) $125-148$.

[7] S. Keysar, Effect of surface roughness on the morphology of calcite crystallizing on mild steel, Journal of Colloid and Interface Science 162 (1994) 311 - 319.

[8] Z. Amjad, Precipitation of calcium carbonate in aqueous solution systems, Tenside Surfactants Detergents 36 (1999) $162-167$.

[9] N.L. Plummer, E. Busenberg, The solubilities of calcite, aragonite and vaterite in $\mathrm{CO}_{2}$ $\mathrm{H}_{2} \mathrm{O}$ solutions between 0 and $90^{\circ} \mathrm{C}$, and an evaluation of the aqueous model for the system $\mathrm{CaCO}_{3}-\mathrm{CO}_{2}-\mathrm{H}_{2} \mathrm{O}$, Geochimica et Cosmochimica Acta 46 (1982) $1011-1040$.

[10] T. Ogino, T. Suzuki, K. Sawada, The formation and transformation mechanism of calcium carbonate in water, Geochimica et Cosmochimica Acta 51 (1987) 2757 - 2767.

[11] C. Hort, A. Martin Dominguez, M. Rola, H. Roques, Etude de l'étape de germination, Tribune de l'eau nº/95 (1995) 3 - 27.

[12] C. Hort, A. Martin Dominguez, C. Rabut, H. Roques, les cinétiques de croissance crystalline, Tribune de l'eau, $n^{\circ} 573 / 1$ (1995) $31-45$.

[13] I. Ben Salah, M.M. Tlili, M. Benamor, Influence of foreign salts to the $\mathrm{CaCO}_{3}-\mathrm{CO}_{2}-\mathrm{H}_{2} \mathrm{O}$ system and antiscalants on the adherence of calcium carbonate on stainless steel, European Journal of Water Quality (41 (2010) $51-66$. 
[14] M.M. Tlili, M. Benamor, C. Gabrielli, H. Perrot, B. Tribollet, Influence of the interfacial $\mathrm{pH}$ on electrochemical $\mathrm{CaCO}_{3}$ precipitation, Journal of the Electrochemical Society 150 (2003) C765 - C771.

[15] F.-A. Setta, A. Neville, Efficiency assessment of inhibitors on $\mathrm{CaCO}_{3}$ precipitation kinetics in the bulk and deposition on a stainless steel surface (316 L), Desalination 281 (2011) 340 - 347 .

[16] H.J. Meyer, The influence of impurities on the growth rate of calcite, Journal of Crystal Growth 66 (1984) $639-646$.

[17] G.H. Nancollas, M.M. Reddy, The crystallization of calcium carbonate. II. Calcite growth mechanism, Journal of Colloid and Interface Science 37 (1971) 824 - 830.

[18] G. Gauthier, Y. Chao, O. Horner, O. Alos-Ramos, F. Hui, J. Lédion, H. Perrot, Application of the Fast Controlled Precipitation method to assess the scale-forming ability of raw river waters, Desalination 299 (2012) 89 - 95.

[19] F. Hui, J. Lédion, Evaluation methods for the scaling power of water, European Journal of Water Quality 33 (2002) $41-52$.

[20] E. Dalas, P.G. Koutsoukos, Calcium Carbonate Scale Formation on Heated Metal Surfaces, Geothermics 18 (1989) $83-88$.

[21] H. Feitler, The scale meter: a new method for determining the critical $\mathrm{pH}$ of scaling, Mater. Prot. Perform. 11 (1972) 31 - 35.

[22] L. Dedieu, Contribution à l'étude des phénomènes d'entartrage. 1ère partie : Généralités et méthodes d'études LCGE, Tribune de l'eau 571 (1994) 3 - 19.

[23] J. Lédion, B. François, J. Vienne, Characterisation of the scaling properties of water by fast controlled precipitation test, Eur. J. Water Qual. 28 (1997) 15 - 35.

[24] C. Gabrielli, H. Perrot, P. Rousseau, A. Belghazi, T. Chevrot, J.M. Colin, C. Simonet, Heated quartz microbalance to study thermally deposited calcareous scale, Review of Scientific Instrument 76, 124102 (2005) 1 - 9.

[25] Z. A, J. Gamby, L. Makhloufi, B. Sotta, B. Tribollet, Inhibition of calcium carbonate precipitation by aqueous extract of Paronychia argentea, Journal of crystal Growth 386 (2014) $208-214$.

[26] C. Gabrielli, Estimation of the deposition rate of thermal calcareous scaling by the electrochemical impedance technique, Journal of Electroanalytical Chemistry 412 (1996) 189 $-193$. 
[27] C. Gabrielli, M. Keddam, A. Khalil, R. Rosset, M. Zidoune, Study of calcium carbonate scales by electrochemical impedance spectroscopy, Electrochim. Acta 42 (1997) 1207 - 1218. [28] Z. Belarbi, J. Gamby, L. Makhloufi, B. Tribollet, Nucleation-growth process of calcium carbonate on rotating disk electrode in mineral potable water, Electrochimica Acta 109 (2013) $623-629$.

[29] C. Gabrielli, G. Maurin, H. Perrot, G. Poindessous, R. Rosset, Investigation of electrochemical calcareous scaling: Potentiostatic current- and mass-time transients, Journal of Electroanalytical Chemistry 538-539 (2002) 133 - 143.

[30] A.M. Abdel-Baber, B.A. Abd-El-Nabey, E. Khamis, D.E. Abd-El-Khalek, A natural extract as scale and corrosion inhibitor for steel surface in brine solution, Desalination 278 (2011) $337-342$.

[31] C. Gabrielli, M. Keddam, A. Khalil, G. Maurin, H. Perrot, R. Rosset, M. Zidoune, Quartz crystal microbalance investigation of electrochemical calcium carbonate scaling, $\mathrm{J}$. Electrochem. Soc. 145 (1998) 2386 - 2396.

[32] A. Khalil, P. Sassiat, C. Colin, C. Meignen, C. Garnier, C. Gabrielli, M. Keddam, R. Rosset, Water scaling tendency charaterisation by coupling constant potential chronoamperometry with quartz crystal microbalance, C. R. Acad. Sci. Paris, IIb 314 (1992) $145-149$.

[33] N. Abdel-Aal, K. Satoh, K. Sawada, Study of adhesion mechanism of calcareous scaling by using quartz crystal microbalance tehcnique, Analytical Science 17 (2001) i825 - i828.

[34] M. Öner, Ö. Doğan, G. Öner, The influence of polyelectrolytes architecture on calcium sulfate dihydrate growth retardation, Journal of Crystal Growth 186 (1998) 427 - 437.

[35] S. Kirboga and M. Öner, Application of experimental design for the precipitation of calcium carbonate in the presence of biopolymer, Powder Technology 249 (2013) 95 - 104. [36] Y. Tang, W. Yang, X. Yin, Y. Liu, P. Yin, J. Wang, Investigation of scale inhibition by PAA, ATMP and PAPEMP, Desalination 228 (2008) $55-60$.

[37] M. Donnet, A. Aimable, J. Lemaître, P. Bowen, Contribution of aggregation to the growth mechanism of seeded calcium carbonate precipitation in the presence of polyacrylic acid, J. Phys. Chem. B 114 (2010) 12058 - 12067.

[38] Z. Amjad, P.G. Koutsoukos, Evaluation of maleic acid based polymers as scale inhibitors and dispersants for industrial water applications, Desalination 335 (2014) 55 - 63. 
[ 39 ] D. Liu, W. Dong, F. Li, F. Hui, J. Lédion, Comparative performance of polyepoxysuccinic acid and polyaspartic acid on scaling inhibition by static and rapid controlled precipitation methods, Desalination 304 (2012) 1 - 10.

[40] Z. Amjad, Interactions of hardness ions with polymeric scale inhibitors in aqueous systems, Tenside Surf. Det. 42 (2005) $71-77$.

[41] W.-Y. Shi, C. Ding, J.-L. Yan, X.-Y. Han, Z.-M. Lv, W. Lei, M.-Z. Xia, F.-Y. Wang, Molecular dynamics simulation for interaction of PESA and acrylic copolymers with calcite crystal surfaces, Desalination 291 (2012) 8-14.

[42] S. Tandy, K. Bossart, R. Mueller, J. Ritschel, L. Hauser, R. Schulin, B. Nowack, Extraction of heavy metals from soils using biodegradable chelating agents, Environ. Sci. Technol. 38 (2004) $937-944$.

[43] D. Hasson, H. Shemer, A. Sher, State of the art of friendly "green" scale control inhibitors: a review article, Ind. Eng. Chem. Res. 20 (2011) 7601 - 7607.

[44] L. Beaunier, C. Gabrielli, G. Poindessous, G. Maurin, R. Rosset, Investigation of electrochemical calcareous scaling: Nuclei counting and morphology, Journal of Electroanalytical Chemistry 501 (2001) $41-53$.

[45] Y. Chao, O. Horner, P. Vallée, F. Meneau, O. Alos-Ramos, F. Hui, M. Turmine, H. Perrot, J. Lédion, In situ probing calcium carbonate formation by combining fast controlled precipitation method and small-angle X-ray scattering, Langmuir 30 (2014) 3303 - 3309.

[46] C. Deslouis, Interfacial $\mathrm{pH}$ measurement during reduction of dissolved oxygen in a submerged impinging jet cell, Journal of Applied Electrochemistry 27 (1997) 482 - 492.

[47] G. Sauerbrey, Verwendung von Schwingquarzen zur Wägung dünner Schichten und zur Mikrowägung, Zeitschrift für Physik 155 (1959) 206 - 222.

[48] M. Fleischmann, H.R. Thirsk, in: P. Delahay (Ed.), Advances Electrochemistry and Electrochemical Engineering, vol. 3, Interscience, New York, 1963, p. 123.

[49] M.Y. Abyaneh, M. Fleischmann, M. Labram, in: R. Weil, R.G. Baradas (Eds.) Proc. Symp. Electrocrystallization, The Electrochemistry Society, New Jersey, Proc. 81 - 6, 1981, p. 1.

[50] C.G. Kontoyannis, and N.V. Vagenas, Calcium carbonate phase analysis using XRD and FT-Raman spectroscopy, Analyst 125 (2000) $251-255$.

[51] J. Lédion, C. Braham, F. Hui, Anti-scaling properties of copper, Journal of Water Supply: Research and Technology 51.7 (2002) 389 - 398. 
[52] M. Euvrard, A. Martinod, A. Neville, Effects of carboxylic polyelectrolytes on the growth of calcium carbonate, Journal of Crystal Growth 317 (2011) $70-78$.

[53] D. Chakraborty, V.K. Agarwal, S.K. Bhatia, J. Bellare, Steady-state transitions and polymorph transformations in continuous precipitation of calcium carbonate, Industrial \& Engineering Chemistry Research 33 (1994) 2187 - 2197.

[ 54 ] C.G. Sinn, R. Dimova, M. Antonietti, Isothermal titration calorimetry of the polyelectrolyte/water interaction and binding of $\mathrm{Ca}^{2+}$ : effects determining the quality of polymeric scale inhibitors, Macromolecules 37 (2004) $3444-3450$.

[55] A. Martinod, A. Neville, M. Euvrad, K. Sorbie, Electrodeposition of a calcareous layer: effect of green inhibitors, Chemical Engineering Science 64 (2009) 2413 - 2421.

[56] Thesis of G. Poindessous, Etude de la germination - croissance du carbonate de calcium par voie électrochimique. Influence de la teneur en oxygène et du transport de matière (1998). [57] N. Wada, K. Kanamura, T. Umegaki, Effects of carboxylic acids on the crystallization of calcium carbonate, J. Colloid Interface Sci. 233 (2001) 65 - 72.

[ 58 ] G.A. Tribello, C.C Liew, M. Parrinello, Binding of calcium and carbonate to polyacrylate, J. Phys. Chem. B 113 (2009) 7081-7085.

[59] A. Martinod, M. Euvrard, A. Foissy, A. Neville, Progressing the understanding of chemical inhibition of mineral scale by green inhibitors, Desalination 220 (2008) $345-352$. 